\title{
PENGEMBANGAN BUKU PENGAYAAN PENGETAHUAN TENTANG PEMBANGKIT LISTRIK TENAGA NUKLIR DILENGKAPI DENGAN AUGMENTED REALITY UNTUK SISWA SMA
}

\author{
Radhita May Putri ${ }^{\text {a) }}$, Anggara Budi Susilab) ${ }^{\text {b) Handjoko Permana }}{ }^{\text {) }}$ \\ Program Studi Pendidikan Fisika, Fakultas Matematika dan Ilmu Pengetahuan Alam, Universitas Negeri \\ Jakarta, Jl. Rawamangun Muka No. 1. Jakarta Timur, 13220

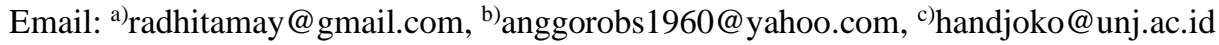

\begin{abstract}
Abstrak
Telah dilakukan penelitian untuk menghasilkan buku pengayaan pengetahuan tentang Pembangkit Listrik Tenaga Nuklir yang dilengkapi oleh Augmented Reality untuk siswa SMA. Buku yang dikembangkan dilengkapi dengan Augmented Reality yang menampilkan animasi 3D dan video, sehingga siswa dapat memvisualisasikan pemahaman dari buku pengayaan. Metode yang digunakan adalah metode penelitian dan pengembangan dengan model 4D serta tahapannya terdiri dari Define, Design, Develop, dan Disseminate. Materi buku berisikan tentang pendahuluan, radioaktivitas dan reaksi inti, reaktor nuklir, dan Pembangkit Listrik Tenaga Nuklir. Buku ditulis dengan menggunakan bahasa yang komunikatif, memberikan fakta-fakta yang menarik mengenai Pembangkit Listrik Tenaga Nuklir, serta dilengkapi dengan ilustrasi dan gambar yang terintegrasi dengan aplikasi Augmented Reality yang dapat bekerja dengan baik pada smartphone dengan sistem operasi android. Instrumen validasi yang digunakan berupa kuisioner skala likert dengan responden para ahli (materi dan media) dan pengguna (guru dan siswa). Hasil validasi uji kelayakan buku pengayaan pengetahuan ini dilakukan oleh ahli materi dengan memperoleh $87,52 \%$.
\end{abstract}

Kata-kata kunci: Buku pengayaan pengetahuan, Pembangkit Listrik Tenaga Nuklir, Augmented Reality

\begin{abstract}
Abstrak
Research has been conducted to produce a knowledge-enrichment book about Nuclear Power Plant equipped with Augmented Reality for high school students. The developed book is equipped with Augmented Reality which displays 3D animations and videos, so students can visualize the understanding of the enrichment book. The method used is research and development method with a 4D model with the stages consists of Define, Design, Develop, and Disseminate. The book material contains the introduction, radioactivity and reaction of the nucleus, nuclear reactor, and Nuclear Power Plant. Books are written using communicative language, provide interesting facts about Nuclear Power Plant, and are equipped with illustrations and images that are integrated with the Augmented Reality application that can work well on smartphones with Android operating system. The validation instrument used was a Likert Scale questionnaire with respondents from experts (material and media) and users (teacher and students). The validation result of feasibility test in this knowledge-enrichment book by material expert obtained $89,33 \%$.
\end{abstract}

Keywords: Knowledge-enrichment book, Nuclear Power Plant, Augmented Reality 


\section{PENDAHULUAN}

Kurikulum terbaru yaitu, kurikulum 2013 mengharuskan peserta didik terlibat aktif dan mandiri dalam pelajaran. Maksud terlibat aktif disini adalah pembelajaran didapat dengan cara peserta didik mencari tahu sendiri, bukan dengan diberi tahu oleh guru lagi. Sehingga peserta didik diharuskan mandiri dalam mendapatkan pengetahuan [1]. Salah satu usaha untuk membuat peserta didik untuk mandiri dalam mendapatkan pengetahuan adalah penggunaan sumber belajar yang tepat. Menurut Seels dan Richey sumber belajar adalah sumber-sumber yang mendukung belajar termasuk sistem penunjang, materi, dan lingkungan pembelajaran [2]. Sebagai sumber belajar, buku teks pelajaran merupakan sumber belajar utama yang digunakan dalam proses pembelajaran [3]. Beberapa materi pembelajaran tidak dapat diajarkan tanpa bantuan buku teks pelajaran. Selain buku teks pelajaran, terdapat buku pengayaan yang dapat digunakan sebagai sumber belajar yang dapat menunjang proses pembelajaran. Buku pengayaan [4] berfungsi sebagai buku penunjang yang dapat memperkaya penguasaan ilmu pengetahuan dan dapat menjadi pelengkap buku teks pelajaran [5].

Perkembangan Teknologi Informasi dan Komunikasi (TIK) telah memberikan kontribusi terhadap terjadinya revolusi dalam berbagai bidang, termasuk bidang pendidikan. Sekarang ini, banyak buku yang sudah diterbitkan dalam bentuk digital atau elektronik (e-book atau electronic book) yang dapat diperoleh baik melalui toko buku ataupun internet [6]. Selain $e$-book, terdapat juga buku dengan Augmented Reality (buku AR) yang digunakan dalam pendidikan. Augmented Reality disini adalah suatu teknologi yang dapat mengintegrasi gambar objek virtual ke dunia nyata [7-8]. Pemanfaatan teknologi AR dalam pembelajaran memiliki kelebihan yaitu dapat melibatkan, merangsang, dan memotivasi peserta didik untuk mengeksplor materi karena dapat memvisualisasikan langsung. Dalam penelitian yang dilakukan Clark dan Dunser terhadap buku AR yang dikembangkannya, membuktikan bahwa penambahan AR pada buku pelajaran dapat meningkatkan pemahaman pembaca [9]. Berdasarkan penelitian Tosun yang berjudul A Study on Reading Printed Books or EBooks: Reasons for Student-Teachers Preferences (2014), bahwa sebanyak 204 dari 258 responden lebih memilih untuk membaca buku cetak daripada buku e-book dengan alasan buku cetak lebih mudah dibaca dan lebih efektif, serta dapat melindungi kesehatan mata [10]. Selain itu, buku cetak masih menjadi sumber belajar yang paling sesuai dengan kebutuhan optik, kognitif, dan metakognitif dari otak ketika membaca [11].

Fisika adalah salah satu cabang Ilmu Sains yang mempelajari fenomena-fenomena alam beserta proses kejadiannya. Salah satu materi Fisika yang menjadi minat bahasan adalah energi. Contoh energi utama yang sering digunakan adalah energi yang berasal dari minyak bumi. Dampak dari penggunaan minyak bumi yang berlebih membuat kita untuk mencari dan mengembangkan sumber energi baru alternatif lainnya [12]. Salah satu alternatif sumber energi baru yang mempunyai potensial adalah energi nuklir. Energi nuklir adalah energi yang dihasilkan selama reaksi nuklir. Reaksi nuklir sendiri terjadi pada inti atom yang pecah atau bergabung menjadi inti atom yang lain dan partikel-partikel lain dengan melepaskan energi kalor. Reaksi nuklir juga bisa terjadi di matahari, reaktor nuklir, dan bom nuklir [13]. Energi nuklir adalah salah satu alternatif sumber energi yang layak untuk dikembangkan. Tetapi, informasi atau penjelasan tentang energi nuklir yang berkembang saat ini hanya seputar tentang penggunaan energi nuklir dalam bentuk bom nuklir dan kecelakaan yang disebabkan nuklir saja. Padahal dengan adanya pemanfaatan energi nuklir yang bijaksana, bertanggung jawab, dan terkendali dapat memberikan solusi atas masalah kelangkaan energi. Dibanding dengan pembangkit listrik yang memanfaatkan bahan bakar fosil, pembangunan Pembangkit Listrik Tenaga Nuklir (PLTN) memang membutuhkan biaya yang mahal tetapi untuk biaya pengoperasiannya relatif lebih murah [14]. Oleh karena itu, wawasan dan pengetahuan tentang pemanfaatan energi nuklir, yaitu PLTN seharusnya lebih disebarkan karena mempunyai dampak positif juga. Berdasarkan uraian yang telah disampaikan di atas, maka perlu dikembangkan buku pengayaan pengetahuan tentang PLTN dilengkapi Augmented Reality yang layak digunakan sebagai buku pengayaan. 


\section{METODE}

Penelitian ini menggunakan metode penelitian dan pengembangan (Research and Development). Sedangkan Model pengembangan yang digunakan yaitu model pengembangan yang dirancang oleh Thiagarajan, dkk yaitu model 4-D. Model 4-D sendiri terdiri dari 4 tahap pengembangan, yaitu Define, Design, Develop, dan Disseminate [15]. Model pengembangan 4-D dipilih karena dapat digunakan untuk berbagai macam pengembangan produk, salah satunya buku [16]. Adapun tahapannya seperti berikut.

Tahap pendefinisian (Define), yaitu melakukan studi literatur untuk pencarian informasi mengenai segala sesuatu yang berkaitan serta relevan dengan buku pengayaan [4, 17] dan Augmented Reality. Lalu dibuat pula kajian materi Fisika yang akan dibuat pada buku pengayaan yang dilengkapi Augmented Reality sesuai dengan kompetensi dasar. Serta melakukan wawancara terhadap guru mata pelajaran Fisika SMA untuk mendapatkan informasi tentang jalannya program pengayaan, ketersedian buku pengayaan, serta kendala dalam melaksanakan pembelajaran. Selain itu, melakukan penyebaran angket ke peserta didik tentang buku pengayaan, bahasan Pembangkit Listrik Tenaga Nuklir (PLTN) dan juga penggunaan smartphone.

Tahap perancangan (Design), yaitu menetukan topik atau materi pokok pembelajaran yang akan dikembangkan yaitu PLTN, menetukan buku-buku atau sumber lainnya yang akan dijadikan rujukan, serta Pemilihan teknologi Augmented Reality pada buku pengayaan untuk membantu memvisualisasikan materi pada buku. Lalu merancang buku mulai dari cover hingga layout buku serta animasi dan video yang akan ditampilkan pada Augmented Reality. Berbagai bentuk dan definisi objek teknologi Augmented Reality dipilih dan dibuat sesuai dengan kajian literatur [18-22], untuk menentukan objek yang cocok dikembangkan dalam produk. Dalam tahap ini, kajian literatur mengenai nuklir juga kami lakukan agar siswa memiliki informasi yang uptodate mengenai perkembangan PLTN di Indonesia [23].

Tahap pengembangan (Develop), yaitu validasi para ahli untuk materi dan media serta uji coba lapangan terhadap guru Fisika dan peserta didik. Adapun tahap ini bertujuan untuk menghasilkan buku pengayaan pengetahuan yang dilengkapi Augmented Reality yang layak sebagai sumber belajar.

Tahap penyebaran (Disseminate), yaitu menyebarluaskan produk secara global. Akan tetapi langkah ini tidak dilakukan karena keterbatasan biaya dan waktu Pengembangan buku pengayaan pengetahuan ini mengacu pada kriteria buku pengayaan yang dikeluarkan oleh Pusat Kurikulum dan Perbukuan (Puskurbuk). Sedangkan untuk aplikasi Augmented Reality yang dikembangkan berdasarkan komponen-komponen seperti interface, objek dan marker dalam aplikasi, serta kamera pemindai.

\section{HASIL DAN PEMBAHASAN}

Pengembangan yang dihasilkan dalam penelitian ini berupa buku pengayaan pengetahuan tentang Pembangkit Listrik Tenaga Nuklir yang dilengkapi Augmented Reality. Buku pengayaan pengetahuan ini menyajikan bab pendahuluan, radioaktivitas dan reaksi inti, reaktor nuklir, serta PLTN. Adapun hasil buku pengayaan pengetahuan yang dikembangkan seperti berikut.
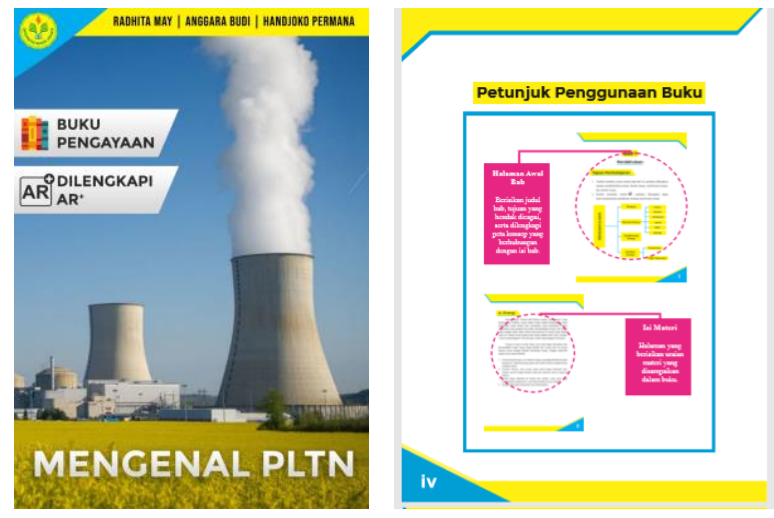

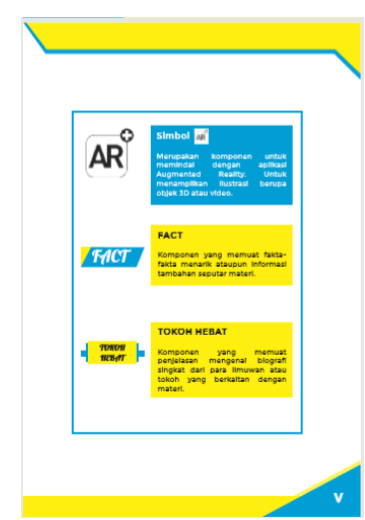



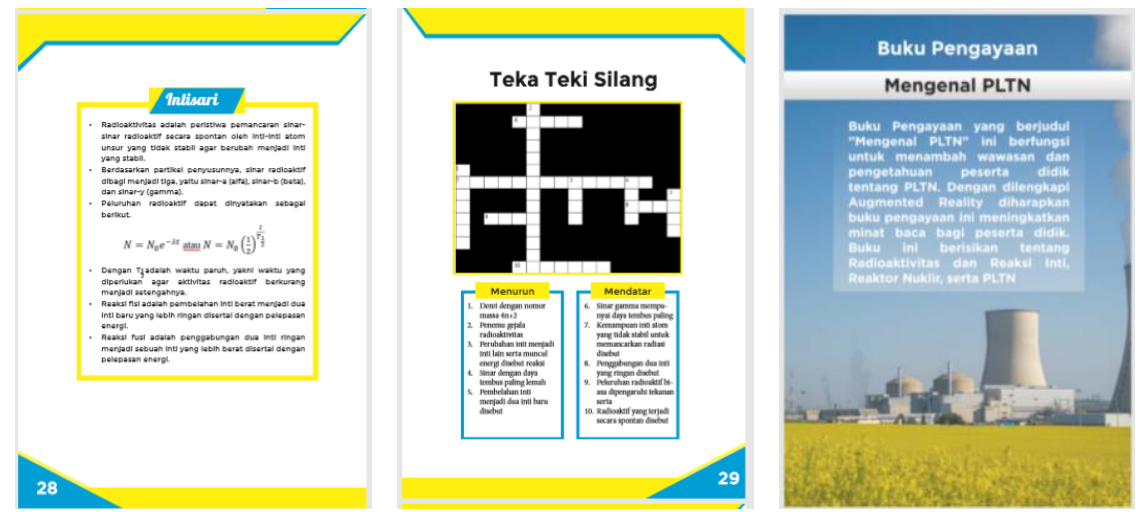

GAMBAR 1. Komponen buku pengayaan pengetahuan mengenal PLTN

Buku pengayaan yang dikembangkan memiliki beberapa komponen yang membedakan dengan buku lain seperti "Fact" yang berisi berbagai fakta-fakta menarik atau informasi tambahan seputar materi yang dibahas, "Tokoh Hebat" yang berisikan penjelasan mengenai biografi singkat dari para ilmuwan atau tokoh yang berkaitan dengan materi, "Intisari" yang berisi rangkuman inti-inti materi dalam setiap babnya., selain itu juga terdapat "Teka Teki Silang" yang berisikan permainan berbentuk teka teki silang terkait materi dalam bab tersebut.

Buku pengayaan ini juga dilengkapi dengan gambar, animasi dan video yang dibantu dengan Augmented Reality untuk menampilkan beberapa objek yang sulit untuk dipahami secara 2D. Augmented Reality yang dihasilkan, menggunakan gambar 2D dalam buku sebagai marker yang akan dipindai dengan smartphone untuk menampilkan objek 3D.

Aplikasi Augmented Reality yang dihasilkan bernama NucleAR Reality Book. Cara menggunakan aplikasi ini dengan mengarahkan kamera dari smartphone Android yang telah terintegrasi aplikasi Augmented Reality ke dalam marker yang terdapat di buku pengayaan. Selanjutnya, hasil yang ditampilkan berupa animasi $3 \mathrm{~d}$ atau video. Aplikasi ini memiliki interface dengan berbagai fungsi, seperti "HINT" yang berisikan petunjuk pemakaian aplikasi, "AR BOOK" halaman untuk mendownload buku pengayaan, "SCAN ME" merupakan kamera untuk memindai gambar, "ABOUT" merupakan halaman tentang aplikasi, serta "HELP" merupakan halaman bantuan apabila aplikasi bermasalah.
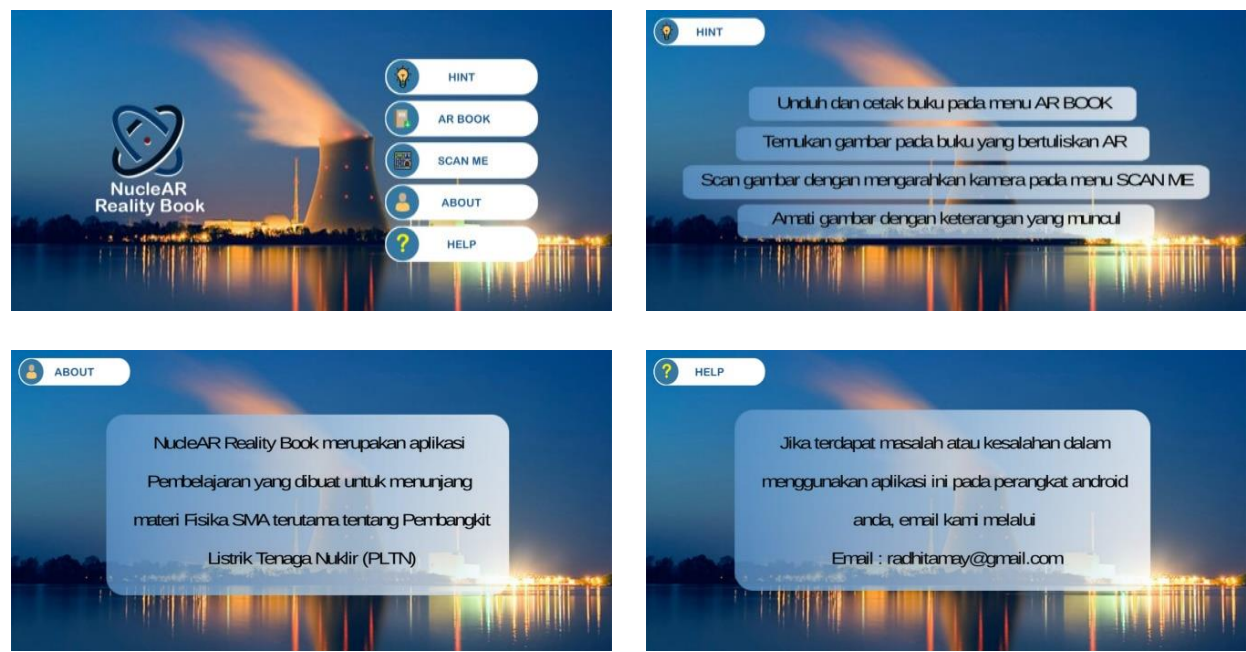

GAMBAR 2. Tampilan aplikasi Augmented Reality

Perlu diketahui bahwa dalam pengembangan ini tidak semua gambar dalam buku pengayaan dapat memuculkan animasi 3D atau video yang terintegrasi aplikasi Augmented Reality. 

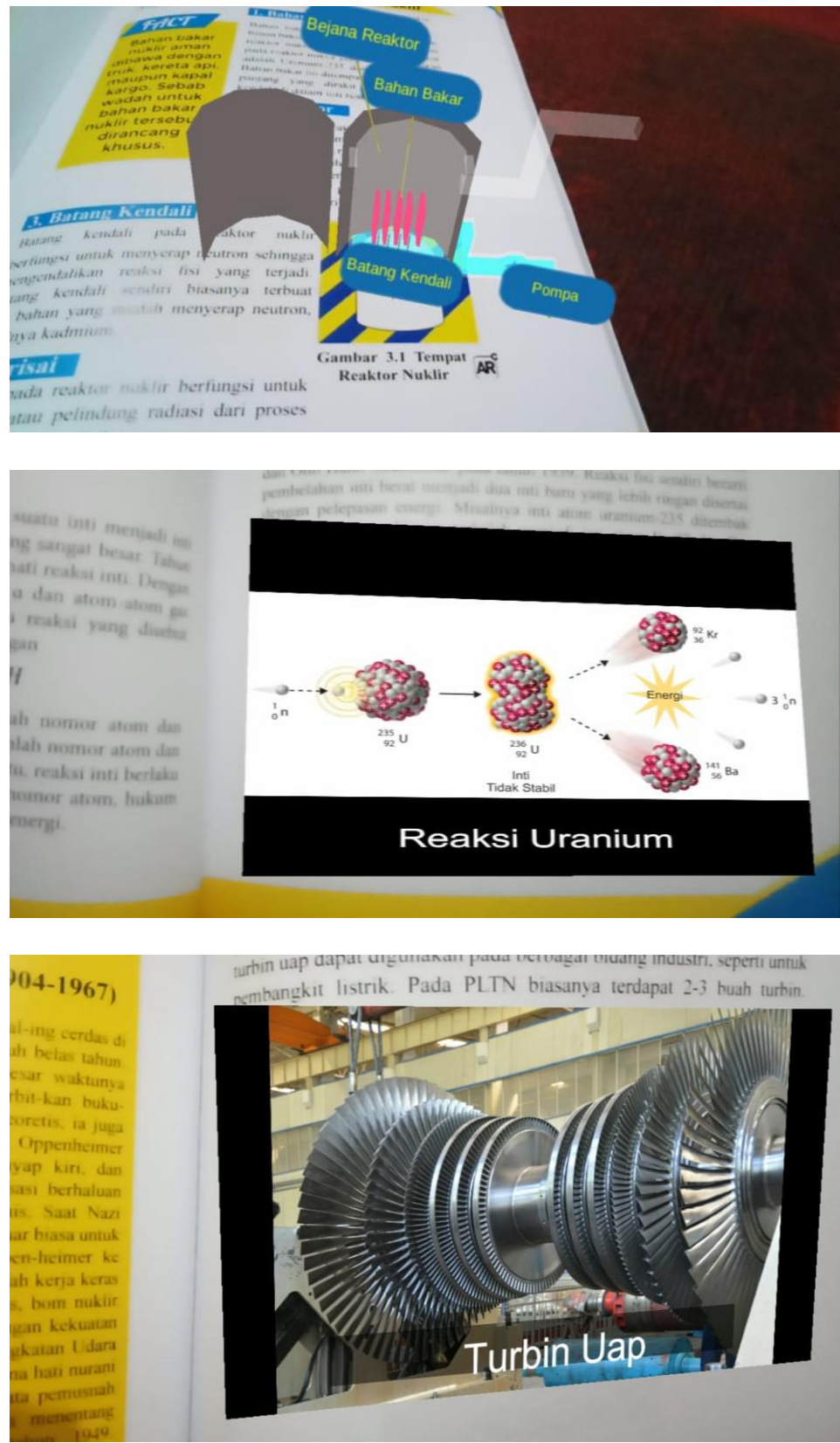

GAMBAR 3. Tampilan animasi 3D dan video buku pengayaan pengetahuan mengenal PLTN

Penjelasan diatas merupakan hasil buku pengayaan dilengkapi Augmented Reality yang dikembangkan. Buku ini bermanfaat untuk menambah wawasan dan pengetahuan, serta dapat menarik minat baca karena dilengkapi dengan Augmented Reality seputar Pembangkit Listrik Tenaga Nuklir (PLTN).

Ahli materi memberikan penilaian pada buku pengayan dilengkapi Augmented Reality yang berjudul "Mengenal PLTN" sudah memenuhi kriteria sangat layak dengan persentase sebesar 87,52\% dengan interpretasi sangat layak pada aspek materi, sajian materi, bahasa serta grafika. Hasil uji kelayakan yang diperoleh dari ahli materi sebagai berikut. 


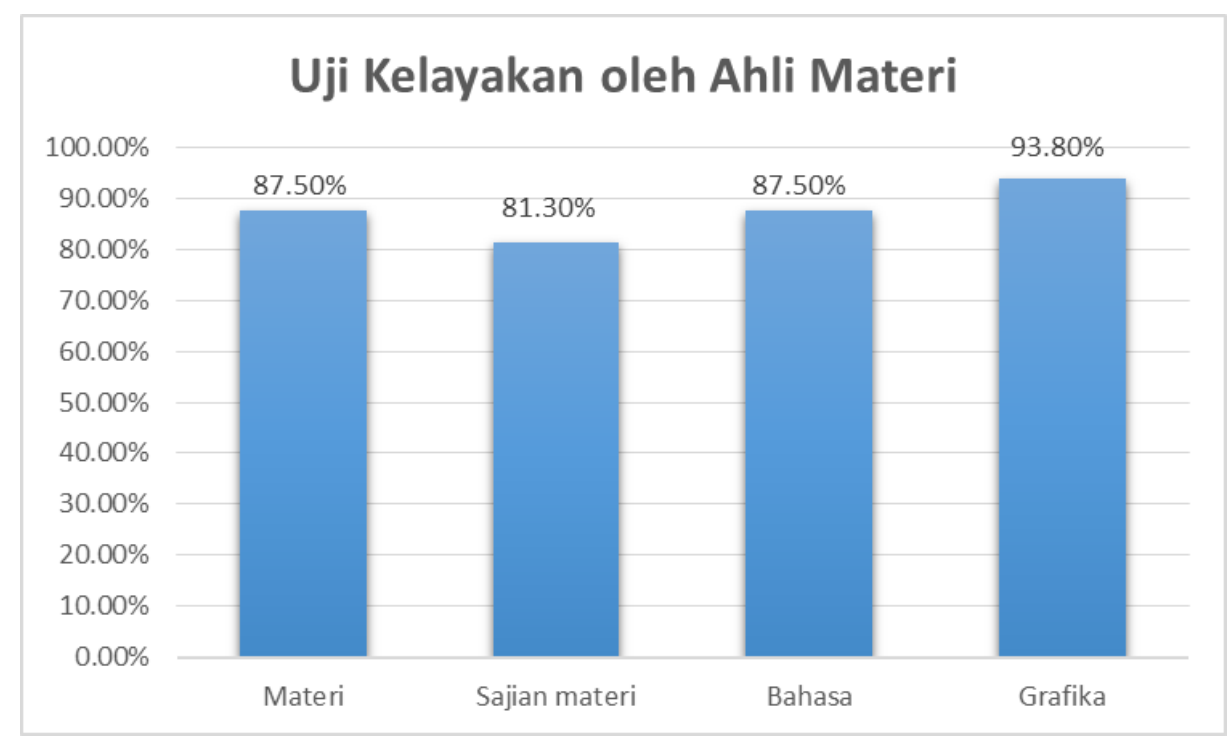

GAMBAR 4. Hasil uji kelayakan oleh ahli materi

\section{PENUTUP}

Berdasarkan, hasil penelitian, buku pengayaan pengetahuan dilengkapi Augmented Reality tentang Pembangkit Listrik Tenaga Nuklir yang dikembangkan memperoleh persentase sebesar $87,52 \%$ oleh ahli materi. Dengan berdasarkan skala kelayakan menyatakan bahwa produk yang dikembangkan layak digunakan sebagai sumber belajar untuk menambah wawasan dan pengetahuan.

\section{UCAPAN TERIMAKASIH}

Terimakasih kepada semua pihak yang telah membantu dan memberikan kritik maupun saran dalam proses pembuatan buku pengayaan pengetahuan dilengkapi Augmented Reality. Referensi yang diberikan sangat bermanfaat dan memberikan arahan yang baik bagi saya.

\section{REFERENSI}

[1] D. Oktarina, "Pembelajaran Fisika Menggunakan Multi Representasi untuk Meningkatkan Kognitif dan Kemampuan Pemecahan Masalah Peserta didik SMA," Prosiding Seminar Nasional Fisika dan Aplikasinya, 2016.

[2] M. Yaumi, Media dan Tekonologi Pembelajaran, Jakarta: Prenadamedia Group, 2018.

[3] F. Bakri, R. Rasyid, and R. D. A. Mulyaningsih, "Pengembangan Modul Fisika Berbasis Visual untuk Sekolah Menengah Atas (SMA)," Jurnal Penelitian dan Pengembangan Pendidikan Fisika, Vol. 1, No. 2, 2015, pp. 67-74.

[4] Desnita, N. Fadilah, and E. Budi, "Pengembangan Buku Pengayaan Kajian Fisis Peristiwa Angin Puting Beliung untuk Siswa SMA," Jurnal Penelitian dan Pengembangan Pendidikan Fisika, Vol. 2, No. 2, 2016, pp. 97-104.

[5] Puskurbuk, Pedoman Penilaian Buku Nonteks Pelajaran, Jakarta: Balitbang Kemendikbud, 2017.

[6] A. R. Saleh, "Peranan Teknologi Informasi dalam Meningkatkan Kegemaran Membaca dan Menulis Masyarakat," Jurnal Pustakawan Indonesia Volume 6 Nomor 1, pp. 42-49, 2016.

[7] S. Maad, Augmented Reality, Croatia: Intech, 2010. 
[8] D. Ambarwulan and D. Muliyati, "The Design of Augmented Reality Application as Learning Media Marker-Based for Android Smartphone," Jurnal Penelitian dan Pengembangan Pendidikan Fisika, Vol. 2, No. 1, 2016, pp. 73-80.

[9] A. Dunser and A. Clurk, "An Interactive Augmented Reality Coloring Book," in IEEE Symp. 3D User Interfaces, pp. 7-10, 2012.

[10] N. Tosun, "A Study on Reading Printed Books or E-books: Reasons for Student-Teacher Preferences," in OJET: The Turkish Online Journal of Educational Technology, vol. 13, 2014, pp. 21-28.

[11] M. Tanner, "Digital vs Print: Reading Comprehension and the Future of the Book," in SLIS Student Research Journal, vol. 4, 2014.

[12] I. Kholiq, "Pemanfaatan Energi Alternatif Sebagai Energi Terbarukan Untuk Mendukung Subtitusi BBM,"in Jurnal IPTEK Volume 19 Nomor 2, 2015, pp. 75-91.

[13] Hamdi, Energi Terbarukan, Jakarta: Prenadamedia Group, 2016.

[14] N. T. Harjanto, "Dampak Lingkungan Pusat Listrik Tenaga Fosil dan Prospek PLTN Sebagai Sumber Energi Listrik Nasional," Jurnal BATAN, Volume 1, Nomor 1, 2008, pp. 39-50.

[15] Trianto, Model Pembelajaran Terpadu, Jakarta: Bumi Aksara, 2010.

[16] E. Mulyatiningsih, Metode Penelitian Terapan Bidang Pendidikan, Bandung: Alfabeta, 2011.

[17] S. Maulana, D. Desnita, and R. Raihanati, "The Development of Knowledge Enrichment Books Concerning Ice and Snow Physical Studies for High-School Students", Jurnal Penelitian dan Pengembangan Pendidikan Fisika, 2018, vol. 4, no. 2, pp. 83 - 90.

[18] H. Permana, H. P. Kencana, F. Bakri, \& D. Muliyati, "The development 3-D augmented reality animation on radioactive concept," Journal of Physics: Conference Series, IOP Publishing, Vol. 1402, No. 6, p. 066076.

[19] W. Indrasari, W, A. S. Budi, \& D. Ambarwulan, "Development ripple tank practicum module to improve the collaborative problem-solving skills with adaptive technology," AIP Conference Proceedings, AIP Publishing, Vol. 2169, No. 1, p. 020005.

[20] F. Bakri, H. P. Kencana, H. Permana, \& D. Muliyati, "The 3-D animation of radiation concept using augmented reality technology," Journal of Physics: Conference Series, IOP Publishing, Vol. 1402, No. 6, p. 066077.

[21] F. Bakri, Oktaviani Marsal, and D. Muliyati, "Textbooks Equipped with Augmented Reality Technology for Physics Topic in High-School", Jurnal Penelitian dan Pengembangan Pendidikan Fisika, 2019, vol. 5, no. 2, pp. 113 - 122.

[22] F. Bakri, D. Ambarwulan, \& D. Muliyati, "Pengembangan Buku Pembelajaran Yang Dilengkapi Augmented Reality Pada Pokok Bahasan Gelombang Bunyi Dan Optik," Gravity: Jurnal Ilmiah Penelitian dan Pembelajaran Fisika, 2018, 4(2).

[23] N. T. E. Hermawan, "Pengembangan Pelatihan Pengangkutan Zat Radioaktif untuk Pemangku Kepentingan yang Terkait", Jurnal Penelitian dan Pengembangan Pendidikan Fisika, 2017, vol. 3, no. 2, pp. 191 - 196. 
